\title{
MENINGKATKAN HASIL BELAJAR SISWA DENGAN PENERAPAN MODEL PEMBELAJARAN INDIVIDUAL DAN PEMBELAJARAN KOOPERATIF DI SMA SWASTA MEDAN
}

\author{
Hotma Tiolina Siregar
}

Surel: tiolinahotma@gmail.com

\begin{abstract}
This study aims to investigate the differences between model and individual model using Mini Lab in Medan. The methodology used in this research is the experimental method with the application of cooperative learning model on the students of class XI-A SMA YPI and in grade XI-A SMA AL-washliyah, then in class XI-B SMA YPI and in class XI-B SMA AL- washliyah using individual models. Data were collected with observation sheets, and biological tests. From the data analysis, the mean of the biological test with cooperative learning model is 7.61 and the standard deviation is 0.34, while the mean of the biology test with the application of individual learning model is 6.09 and the standard deviation is 0.34. Then test the hypothesis with $t$ test show> $t$ table, then ho rejected and alternatife excluded. The results show that there is a difference between the learning model and the model using a mini lab at a private school in Medan.
\end{abstract}

Keywords: Cooperative Learning, Individual Learning Model, Mini Lab.

\begin{abstract}
ABSTRAK
Penelitian ini bertujuan untuk menyelidiki perbedaan antara model dan model individu menggunakan Mini Lab di Medan. Metodologi yang digunakan dalam penelitian ini adalah metode eksperimen dengan penerapan model pembelajaran kooperatif pada siswa kelas XI-A SMA YPI dan di kelas XI-A SMA ALwashliyah, kemudian pada kelas XI-B SMA YPI dan di kelas XI-B SMA AL washliyah menggunakan model individu. Data dikumpulkan dengan lembar observasi, dan tes biologi. Dari analisis data, rata-rata tes biologi dengan alat model pembelajaran kooperatif adalah 7,61 dan standar deviasi 0,34, sedangkan rata-rata tes biologi dengan penerapan model pembelajaran individu adalah 6,09 dan standar deviasi adalah 0,34. Kemudian uji hipotesis dengan $t$ test show> $t$ table, maka ho ditolak dan alternatife dikecualikan. Hasilnya menunjukkan bahwa ada perbedaan antara model pembelajaran dan model menggunakan mini lab di sekolah swasta di Medan.
\end{abstract}

Kata Kunci: Pembelajaran Kooperatif, Model Pembelajaran Individual, Mini Lab.

\section{PENDAHULUAN}

Kegiatan

merupakan bagian penting dalam menunjang mata pelajaran IPA di SMA. Oleh sebab itu, diharapkan kepada guru agar melakukan kegiatan praktikum setelah memberikan teori pada mata pelajaran IPA, yang melibatkan aktivitas siswa, baik aktivitas fisik 
maupun mental emosional siswa. Kegiatan praktikum merupakan kegiatan yang dapat dilakukan diluar kelas, didalam kelas dan di laboratorium, namun kenyataannya masih banyak sekolah-sekolah swasta yang tidak memiliki fasilitas laboratorium untuk menunjang kegiatan belajar mengajar disekolah, sehingga sekolah tersebut tidak melakukan kegiatan praktikum kepada siswa.

Menurut Dahar R.W. (1989), Mini lab adalah kegiatan praktikum yang dilakukan didalam kelas dengan peralatan yang minimum dapat melakukan kegiatan praktikum untuk menunjang kegiatan teori yang telah diperoleh oleh siswa sebelumnya. Kegiatan praktikum yang seharusnya dilakukan di laboratorium khusus, maka dengan mini lab kegiatan praktikum dilakukan didalam kelas bagi sekolah-sekolah yang tidak memiliki fasilitas laboratorium bagi siswanya. Selama berlangsungnya kegiatan mini lab di kelas terjalin suatu interaksi sosial antara guru dan siswa, siswa dengan siswa yang juga merupakan jaringan komunikasi, sehingga terbentuk masyarakat kelas antara siswa dengan guru.

Mini lab memberikan siswa kesempatan untuk menyelidiki dan menentukan dengan bekerja dalam kelompok atau bekerja individual. Model pembelajaran kooperative suatu pendekatan belajar dengan cara siswa belajar dalam sekelompok kecil dengan tingkatan kemampuan berbeda dalam melakukan kegiatan praktikum mini lab, maka mini lab dapat dilakukan dengan model pembelajaran kooperatif dimana siswa bekerja dalam kelompok yang terdiri atas 4-5 siswa yang saling kerjasama dalam melakukan kegiatan mini lab, model pembelajaran individual merupakan suatu sistem yang disesuaikan dengan keadaan perseorangan, meliputi antara lain kemampuan dan kecepatan belajar dalam melakukan kegiatan praktikum dengan menggunakan mini lab.

Secara khusus istilah "model" diartikan sebagai kerangka konseptual yang digunakan sebagai pedoman dalam melakukan sesuatu kegiatan (menurut Sokanto \& Putra 1997). Model pembelajaran adalah kerangka konsep yang melukiskan prosedur yang sistematis dalam mengorganisasikan pengalaman belajar untuk mencapai tujuan belajar tertentu dan berfungsi sebagai pedoman bagi para perancang pembelajaran dan para pengajar dalam merencanakan dan melaksanakan aktivitas belajar mengajar.

Model pembelajaran kooperatif merupakan suatu pendekatan belajar dengan cara siswa belajar dalam sekelompok kecil dengan tingkat kemampuan yang berbeda, saling membantu untuk memahami suatu pelajaran, memeriksa dan memperbaiki jawaban teman, seta kegiatan lainnya dengan tujuan mencapai hasil belajar tinggi (Lie, 2002). Lima unsur model pembelajaran kooperatif harus 
ditetapkan oleh siswa yaitu: a. Saling Keterangan Positif, untuk menciptakan kelompok kerja yang efektif, pengajar perlu menyusun tugas sedemikian rupa sehingga setiap kelompok harus menyelesaikan tugasnya sendiri. $b$. Tanggung Jawab Individu, untuk mempersiapkan semua anggota kelompok dapat menyelesaikan tugas yang serupa secara mandiri. c. Tatap Muka, setiap kelompok harus diberikan kesempatan untuk bertemu muka dan berdiskusi. d. Komunikasi Antar Anggota, unsur ini juga menghendaki agar para pembelajaran dibekali dengan berbagai keterampilan komunikasi. e. Evaluasi Proses Kelompok, pengajar perlu menjadwalkan waktu khusus untuk mengevaluasi proses kerja kelompok dengan hasil kerja sama mereka agar selanjutnya bisa bekerja sama lebih efektif. Adapun langkah-langkah model pembelajaran kooperatif menurut (Karli H \& Yuliariatiningsih M, 2002) adalah: (1) guru merangcang pembelajaran, mempertimbangan dan menetapkan target pembelajaran yang ingin dicapai dalam pembelajaran. (2) dalam aplikasi pembelajaran dikelas, guru merancang lembar observasi kegiatan siswa dalam belajar secara bersama-sama dalam kelompokkelompok kecil. (3) dalam melakukan observasi kegiatan siswa, guru mengarahkan dan membimbing siswa baik secara individual maupun kelompok. (4) guru memberikan kesempatan siswa untuk mempersentasikan hasil kerjanya.
Model Pembelajaran Individual merupakan suatu sistem yang kompleks disesuaikan dengan keadaan perseorangan meliputi antara lain kemampuan dan kecepatan belajar siswa (Hamalik, 2002). Model pembelajaran individual menerapkan pendirian dasar dengan melaksanakan bimbingan kepada siswa secara mandiri, agar mampu menguasai keterampilan pengetahuan dan sikap yang berpusat kepada siswa. Dalam hal ini guru hanya sebagai fasilitator dan komentator, serta guru memberikan perhatian yang lebih kepada siswa, karena siswa secara mandiri pemecahan masalah / materi pelajaran. Dapat dijelaskan bahwa tugas-tugas guru dalam system belajar individual, guru memberi perhatian kepada setiap perbedaan siswa secara individual, yaitu dapat memberikan bantuan kepada setiap siswa yang memerlukan bantuan, dan membri dorongan kepada siswa yang kehilangan motivasi, mengajukan pertanyaan-pertanyaan bagi siswa yang lebih maju, dalam hal ini secara keseluruhan tugas guru adalah mengatur supaya siswa dapat berinteraksi dengan bahan-bahan belajar yang disediakan untuk mencapai tujuan pembelajaran.

Tujuan pembelajaran kooperatif untuk memberikan kesempatan kepada siswa untuk terlibat secara aktif proses berfikir dan kegiatan belajar didalam kelas, siswa belajar dalam kelompok kecil dengan tingkat kemampuan yang berbeda, saling membantu untuk 
memahami suatu $\begin{array}{r}\text { pelajaran, } \\ \text { memeriksa } \\ \text { dan }\end{array}$ memperbaik jawaban teman, serta kegiatan lainnya dengan tujuan mencapai hasil belajar tertinggi. Sedangkan tujuan pembelajaran individu agar siswa secara individu dapat belajar secara efisien, bergairah mencapai tujuan instruksional yang telah dirumuskan dengan jelas dan singkat, siswa mendapat perhatian dari setiap guru pada saat terjadi proses mengajar dikelas agar setiap anak dapat belajar dengan berhasil.

Media berasal dari bahasa latin merupakan bentuk jamak dari "Medium" yang secara harfiah berarti "Perantara" atau "Pengantar" yaitu perantara atau pengantar sumber pesan dengan penerima pesan. Dalam Proses belajar mengajar di kelas, Media berarti sebagai sarana yang berfungsi menyalurkan pengetahuan dari Guru kepada peserta didik. Kelancaran Aplikasi Model Pembelajaran sedikit banyak ditentukan pula oleh Media Pembelajaran yang digunakan. Beberapa ahli memberikan definisi tentang media pembelajaran. Penggunaan media pembelajaran dalam penelitian Kuantitatif maupun Kualitatif juga menjadi ukuran penting dalam proses pembuktian hipotesa.

Pengertian Media Pembelajaran menurut para ahli:

a. Schramm mengemukakan bahwa media pembelajaran adalah teknologi pembawa pesan yang dapat dimanfaatkan untuk keperluan pembelajaran.

b. Briggs (1977) berpendapat bahwa media pembelajaran adalah sarana fisik untuk menyampaikan isi/materi pembelajaran seperti: buku, film, video dan sebagainya. Sedangkan.

c. National Education Associaton (1969) mengungkapkan bahwa media pembelajaran adalah sarana komunikasi dalam bentuk cetak maupun pandangdengar, termasuk teknologi perangkat keras.

d. Brown (1973) mengungkapkan bahwa media pembelajaran yang digunakan dalam kegiatan pembelajaran dapat mempengaruhi terhadap efektivitas pembelajaran. Pada mulanya, media pembelajaran hanya berfungsi sebagai alat bantu guru untuk mengajar yang digunakan adalah alat bantu visual.

Jenis-jenis Media Pembelajaran:

a. Media Audio. Media audio berfungsi untuk menyalurkan pesan audio dari sumber pesan ke penerima pesan. Media audio berkaitan erat dengan indra pendengaran.contoh media yang dapat dikelompokkan dalam media audio diantaranya: radio, tape recorder, telepon, laboratorium bahasa, dll.

b. Media Visual. Media visual yaitu media yang 
mengandalkan indra penglihat. Media visual dibedakan menjadi dua yaitu media visual diam dan media visual gerak

c. Media audio visual. Media audiovisual merupakan media yang mampu menampilkan suara dan gambar. Ditinjau dari karakteristiknya media audio visual dibedakan menjadi 2 yaitu (1) madia audio visual diam, dan media audio visual gerak.

d. Media Serbaneka. Media serbaneka merupakan suatu media yang disesuaikan dengan potensi di suatu daerah, di sekitar sekolah atau di lokasi lain atau di masyarakat yang dapat dimanfaatkan sebagai media pengajaran. Contoh media serbaneka diantaranya : Papan tulis, media tiga dimensi, realita, dan sumber belajar pada masyarakat.

Metode eksperimen menurut Djamarah adalah cara penyajian pelajaran, dimana siswa melakukan percobaan dengan mengalami sendiri sesuatu yang dipelajari, dalam proses belajar mengajar, dengan metode eksperimen, siswa diberi kesempatan untuk mengalami sendiri atau melakukan sendiri, mengikuti suatu proses, mengamati suatu objek, keadaan atau proses. Dengan demikian siswa dituntut untuk mengalami sendiri, mencari kebenaran atau mencoba untuk menarik kesimpulan dari proses yang dialaminya.
Tahap-tahap metode eksperimen: (1) percobaan awal, pembelajaran diawali dengan melakukan percobaan yang didemonstrasikan guru. pengamatan, siswa diharapkan mengamati dan mencatat yang didemonstrasikan. (3) hipotesis awal, siswa dapat merumuskan hipotesis sementara berdasarkan hasil pengamatan. (4) verifikasi, siswa diharapkan merumuskan hasil percobaan dan membuat kesimpulan serta melaporkannya. (5) aplikasi konsep, siswa mengaplikasikannya dalam kehidupannya. (6) evaluasi, merupakan kegiatan akhir setelah selesai satu konsep.

Mini lab adalah kegiatan praktikum yang dilakukan didalam kelas dengan peralatan yang minimum dapat melakukan kegiatan praktikum untuk menunjang kegiatan teori yang telah diperoleh oleh siswa sebelumnya. Kegiatan praktikum yang seharusnya dilakukan di laboratorium khusus, maka dengan mini lab kegiatan praktikum dilakukan didalam kelas bagi sekolah-sekolah yang tidak memiliki fasilitas laboratorium bagi siswanya. Adapun keunggulan dari mini lan adalah: a. sekolah-sekolah yang tidak memiliki laboratorium, dapat melakukan praktikum didalam kelas, b.dengan peralatan yang minimum siswa dapat melakukan kegiatan praktikum, c. mempermudah siswa berhadapan dengan objek langsung, d. dapat membimbing siswa dalam menemukan sendiri, e. melatih siswa berpikir kritis. Apabila kegiatan mini 
lab dilakukan, maka hendaknya diperhatikan: (1) percobaan tidak menghasilkan gas beracun. (2) zat dan alat sudah tersedia untuk setiap individu maupun kelompok. (3) percobaan tidak berbahaya.

Mini lab memberikan siswa kesempatan untuk menyelidiki dan menentukan dengan bekerja dalam kelompok kooperatif atau bekerja secara individual. Aktifitas yang dilakukan dengan menggunakan mini lab ini dibantu dengan lembar kerja siswa yang berisikan: (a) pernyataan yang akan dibahas (b) daftar material yang diperlukan (c) langkah-langkah melakukan praktikum menganalisis data dan membuat kesimpulan (e) pertanyaanpertanyaan untuk membantu siswa memeriksa observasinya.

$$
\text { Adapun Kelebihan dan }
$$
kelemahan Mini lab antara lain: (1) Anak didik dapat aktif mengambil bagian untuk diri sendiri. (2) ia mendapat kesempatan sebesarbesarnya untuk melaksanakan langkah-langkah dalam cara-cara berpikir ilmiah. (3) mereka lebih aktif berpikir dan berbuat. (4) menarik dan menyenangkan bagi siswa. (5) siswa dapat memperoleh fakta-fakta yang jelas. (6) memupuk keberanian untuk berbuat. Kelemahan Mini lab antara lain: (1) memerlukan jangka waktu yang lama (2) kurangnya persiapan dan pengalaman anak didik. (3) tidak semua topic dapat diajarkan melalui metode ini. (4) memerlukan waktu dan biaya tidak sedikit. memerlukan perencanaan yang rumit dan matang dari guru yang akan mengajar.

\section{METODE PENELITIAN}

Penelitian adalah metode eksperimen, metode eksperimen diamati dalam bentuk observasi. Berdasarkan jenisnya, maka penelitian ini termaksud kedalam metode eksperimen semu. Variabel penelitian ini terdiri atas: 1. Variabel terikat, yakni hasil belajar dan social skill pokok bahasan sistem reproduksi tumbuhan. 2. Variabel bebas, yakni model pembelajaran kooperatif dan model pembelajaran individual.

Populasi dari penelitian ini adalah seluruh siswa SMA Kelas XI yaitu SMA Swasta YPI dan SMA Swasta AL-Waslyah yang terdiri atas: 2 kelas siswa SMA Swasta YPI yang berjumlah 80 siswa dan 2 kelas siswa SMA Swasta AL-Waslyah yang berjumlah 80 siswa, jadi keseluruhan populasi berjumlah 160 siswa, sedangkan Sampel penelitian ini adalah sebanyak 80 siswa yang terdiri dari 40 siswa SMA Swasta YPI kelas XI dan 40 siswa SMA Swasta AL-waslyah kelas XI.

Adapun lembar observasi dalam penelitian ini adalah: 1) Lembar observasi aktivitas guru dan siswa dalam pembelajaran, 2)Lembar observasi keterampilan kooperatif dan individual siswa, 3) Perangkat dan hasil belajar. Dalam penelitian metodologi yang digunakan, yakni metode eksperimen, penelitian eksperimen ini dilakukan dalam tiga tahap, yakni tes awal, kegiatan 
pembelajaran kooperatif dan individual dan dilanjutkan tes akhir.

\section{HASIL PENELITIAN DAN PEMBAHASAN}

Hasil Belajar Biologi Kelas

XI-A SMA Swasta YPI dengan Pembelajaran Kooperatif, berdasarkan data yang diperoleh dari hasil penelitian dengan jumlah subjek 20 orang diperoleh nilai tertinggi 8,6 dan nilai terendah 6,9 dengan rata-rata nilai $(\mathrm{M})=7,89$ dan standart deviasi $(\mathrm{SD})=0,54$.

Hasil Belajar Biologi Kelas XI-B SMA Swasta YPI dengan Pembelajaran Individual, berdasarkan data yang diperoleh dari hasil penelitian dengan jumlah subjek 20 orang diperoleh nilai tertinggi 66 dan nilai terendah 5,4 dengan rata-rata nilai $(\mathrm{M})=6,13$ dan standart deviasi $(\mathrm{SD})=0,27$.

Hasil Belajar Biologi Kelas XI-A SMA Swasta AL-Waslyah dengan Pembelajaran Kooperatif, berdasarkan data yang diperoleh dari hasil penelitian dengan jumlah subjek 20 orang diperoleh nilai tertinggi 8 dan nilai terendah 6,9 dengan rata-rata nilai $(\mathrm{M})=7,33$ dan standart deviasi $(\mathrm{SD})=0,33$.

Hasil Belajar Biologi Kelas

XI-B SMA Swasta AL-Waslyah dengan Pembelajaran Individual, berdasarkan data yang diperoleh dari hasil penelitian dengan jumlah subjek 20 orang diperoleh nilai tertinggi 6,9 dan nilai terendah 5,4 dengan rata-rata nilai $(\mathrm{M})=6,06$ dan standart deviasi $(\mathrm{SD})=0,41$. $\begin{array}{ccr}\text { Hasil } & \text { Observasi } & \text { pada } \\ \text { Keterampilan } & \text { Kooperatif } & \text { Siswa }\end{array}$ Kelas XI-A SMA Swasta YPI, berdasarkan data yang diperoleh dari hasil penelitian dengan jumlah subjek 20 orang diperoleh nilai tertinggi 9,7 dan nilai terendah 6,3 dengan rata-rata nilai $(\mathrm{M})=7,98$ dan standart deviasi $(\mathrm{SD})=1,03$.

Hasil Observasi pada Keterampilan Individual Siswa Kelas XI-B SMA Swasta YPI, berdasarkan data yang diperoleh dari hasil penelitian dengan jumlah subjek 20 orang diperoleh nilai tertinggi 6,9 dan nilai terendah 5,4 dengan ratarata nilai $(\mathrm{M})=6,19$ dan standart $\operatorname{deviasi}(\mathrm{SD})=0,24$.

Hasil Observasi pada Keterampilan Kooperatif Siswa Kelas XI-A SMA AL-Waslyah, berdasarkan data yang diperoleh dari hasil penelitian dengan jumlah subjek 20 orang diperoleh nilai tertinggi 9,2 dan nilai terendah 7,9 dengan rata-rata nilai $(M)=8,6$ dan standart deviasi $(\mathrm{SD})=0,45$.

Hasil Observasi pada Keterampilan Kooperatif Siswa Kelas XI-B SMA AL-Waslyah, berdasarkan data yang diperoleh dari hasil penelitian dengan jumlah subjek 20 orang diperoleh nilai tertinggi 7 dan nilai terendah 5,7 dengan rata-rata nilai $(M)=6,2$ dan standart deviasi $(\mathrm{SD})=0,33$.

Pengujian Persyaratan Analisis

Dalam pengujian analisis statistik untuk menguji hipotesis, maka dilakukan uji normalitas dan homogenitas. (1). Uji normalitas 
bertujuan untuk mengetahui normal tidaknya data tiap variabel penelitian, untuk menguji normalitas data digunakan uji liliefors. Uji normalitas diperoleh L0 $<$ L1 sehingga demikian dapat disimpulkan bahwa data setiap variabel penelitian adalah berdistribusi normal. (2). Uji homogenitas data yang digunakan uji stastiktik.

\section{Pengujian Hipotesis}

Berdasarkan uji hipotesis, ditemukan bahwa: (a) pengujian hipotesis data pre-test, terdapat harga t hitung 1,448 dan bila dibandingkan dengan $\mathrm{t}$ tabel $=1,698$, maka $\mathrm{t}$ hitung $<\mathrm{t}$ tabel, sehingga Ho diterima dan dapat disimpulkan bahwa "tidak terdapat perbedaan hasil belajar siswa sebelum menerapkan model pembelajaran. (b) pengujian hipotesis data post-test, terdapat harga $\mathrm{t}$ hitung 34,031 dan bila dibandingkan dengan $\mathrm{t}$ tabel $=1,698$, maka $\mathrm{t}$ hitung > t tabel, maka Ho ditolak dan Ha diterima. Sehingga dapat disimpulkan bahwa "terdapat perbedaan yang signifikan hasil belajar kooperatif dan individual dengan menggunakan mini lab". Untuk mengetahui adanya pengaruh keterampilan siswa terhadap hasil belajar biologi digunakan rumus kolerasi dengan kriteria penerimaan jika $\mathrm{r}$ hitung $>\mathrm{r}$ tabel pada taraf nyata $=0,05$, maka dapat dikatakan ada pengaruh. Untuk semua data di peroleh rhitung > rtabel, sehingga dapat disimpulkan terdapat hubungan yang signifikan antara keterampilan (sosial skill) siswa dengan hasil belajar biologi.

Temuan Penelitian

Berdasarkan analisis data dikemukakan penemuan sebagai berikut: (1) dari pengolahan data pretes dan data post-tes diketahui bahwa sampel distribusi normal. (2) dari pengolahan data pre-tes diketahuiada perbedaan hasil belajar sebelum diterapkan model pembelajran. (3) nilai rata-rata hasil belajar dengan model pembelajaran kooperatif sebesar 7,61 dengan standar deviasi sebesar 0,34, sedangkan nilai ratarata hasil belajar dengan model pembelajaran individual sebesar 6,09 dengan standar deviasi sebesar 0,34. (4) terdapat perbedaan yang signifikan hasil belajar dengan menerapkan model pembelajaran kooperatif dan individual dengan menggunakan mini lab. (5) terjadi perbedaan tersebut dikarenakan pada siswa yang mendapat pembelajaran kooperatif lebih aktif, proses belajar siswa terlibat secara intelektual, betul-betul berperan dan berpartisipasi aktif didalam melakukan kegiatan belajar. (6) keterampilan kooperatif dan individual siswa dapat mempengaruhi hasil belajar siswa, dalam arti semakin tinggi keterampilan siswa maka hasil belajarnya akan semakin baik.

\section{Pembahasan}

Dilihat dari hasil penelitian, hasil belajar biologi siswa dengan penerapan model pembelajaran kooperatif lebih tinggi dibandingkan 
dengan model pembelajaran individual. Hal ini dapat dilihat dari nilai rata-rata siswa yang diterapkan model pembelajaran kooperatif sebesar 7,61 dengan standar deviasi sebesar 0,34 , sedangkan nilai ratarata hasil belajar dengan model individual sebesar 6,09 dengan atandar deviasi sebesar 0,34. Adanya perbedaan itu, karena penerapan model pembelajaran kooperatif memberikan kesempatan kepada siswa untuk terlibat secara aktif dalam proses berfikir dan kegiatan belajarnya dikelas. Siswa dalam kelompok kecil dengan tingkat kemampuan yang berbeda, saling membantu untuk memahami satu pelajran, meriksa dan memperbaiki jawaban teman, serta kegiatan lainnya dengan tujuan mencapai hasil belajar tinggi.

\section{SIMPULAN}

Simpulan hasil penelitian ini adalah: (1) ada perbedaan hasil belajar biologi kelompok siswa yang belajar dengan menerapkan model pembelajaran kooperatif sebesar 7,61 dengan standar deviasi sebesar 0,34 dan nilai rata-rata hasil belajar dengan model pembelajaran individual sebesar 6,09 dengan standar deviasi sebesar 0,34. (2) hasil belajar biologi siswa yang belajar dengan menerapkan model pembelajaran kooperatif lebih baik daripada hasil belajar biologi siswa yang menggunakan model pembelajaran dindividual.

keterampilan (social skill) siswa dapat mempengaruhi hasil belajar biologi siswa.

Untuk menghasilkan siswa dengan prestasi yang baik, para guru dituntut menguasai berbagai model pembelajaran yang akan digunakan dalam kegiatan belajar mengajar, dengan menerapkan model pembelajaran kooperatif diharapkan timbul suatu komunikasi aktif antara siswa dalam diskusi, dan dianjurkan kepada guru yang mengajar agar tetap membimbing dan mengarahkan siswa dalam proses pembelajaran berlangsung. Dalam pembelajaran bidang studi biologi, akan tercapai prestasi yang lebih baik apabila sekolah memiliki fasilitas laboratorium yang mendukung untuk mengadakan praktikum, serta guru dapat menerapkan model-model pembelajaran yang sesuai dengan materi yang dipelajarinya.

Menerapkan

Model

Pembelajaran Kooperatif dengan Menggunakan Minilab akan membantu siswa untuk memahami konsep, pemahaman konsep dapat diketahui apabila siswa mampu mengutarakan secara lisan, tulisan maupun aplikasi dalam kehidupannya. Dengan kata lain siswa memiliki kemampuan untuk menjelaskan, menyebutkan, memberikan contoh dan menerapkan konsep terkait dengan pokok bahasan

\section{DAFTAR RUJUKAN}

Arikunto, Suharsimi. 2006. Dasardasar evaluasi Pendidikan. Jakarta : Bumi Aksara. 
Hotma Tiolina Siregar: Penerapan Model Pembelajaran...

Dahar, R. W. 1989. Teori-teori belajar. Jakarta: Erlangga.

Djamarah, S.B. Zain A. 2002. Strategi Belajar Mengajar. Jakarta: Rineka Cipta.

Faisal, S. 1992. Metodologi Pendidikan. Surabaya: Usaha Nasional.

Hamalik, O. 2002. Proses Belajar Mengajar. Jakarta Bumi Aksara.

Irianto, A. 2004. Statistik Konsep Dasar dan Aplikasinya. Jakarta: Prenada Media.

Jalaluddin. Idi A. 1997. Filsafat Pendidikan. Jakarta: Gaya Media Pertama.

Karli. H. Yuliartiningsih M. 2002. Implementasi Kurikulum Berbasis Kompetisi. Bandung: Bima Media Informasi.

Lie. A. 2004. Kooperatife Learning. Jakarta: Grasindo.

Mulyasa. 2002. Kurikulum Berbasis Kompetisi. Bandung: Remaja Rosdakarya.

Mudjijo. 1990. Belajar Mudah Penelitian. Bandung: Bumi Aksara.

Sudjana. 1992. Metode Statistika. Bandung: Tarsito.

Sudijono. A. 2004. Statistik Pendidikan. Jakarta: Raja Grafindo.

Sudjadi. B. 2005. Biologi. Surabaya: Yudistira.

Sukardi. 2004. Metodologi Penelitian Pendidikan. Jakarta: Bumi Aksara. 